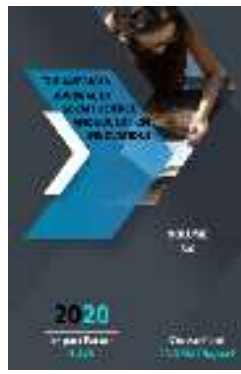

\title{
The Position Of Nongovernmental Offices In Supporting Business Women
}

\author{
Mahfuzakhon Khuja Kizi Shamsieva \\ PhD In History, Teacher Of Ferghana State University, Ferghana Region, Republic of \\ Uzbekistan
}

\begin{abstract}
Journal Website: http://usajournalshub.c om/index,php/tajssei

Copyright: Original content from this work may be used under the terms of the creative commons attributes 4.0 licence.
\end{abstract}

\section{ABSTRACT}

This article is devoted to women who have been starting their business and supporting them in financial sphere by government in Uzbekistan, there is special model such as Business woman association and Shark ayoli. Here is given fruitful information about these associations in this article.

\section{KEYWORDS}

Population, employment, girls-women, business women, Shark ayoli, more mental strategies, economy, nongovernmental association, project.

\section{INTRODUCTION}

The problem of employment exists at different levels in all countries, regardless of their level of economic and social development. In the context of economic liberalization, an increase in the current level of unemployment among the able-bodied population from the natural level will be costly for society, both economically and socially. Experts estimate that the world's population will reach 5.0 billion in 1987, 6 billion in 2000, and 8 billion in 2025. The population of Uzbekistan was estimated at 20.4 million in 1990, almost 25 million in 2000, 29 million in 2010, 31 million in 2015, more than 34 million in 2020, and 35 million in 2025 [1]. 


\section{METHODS}

This shows that the problem of employment should be given more attention around the world, including in our country. The ongoing socio-economic reforms in our country, aimed at further liberalization and modernization of the economy, serve to create new jobs in employment. In particular, the Law of the Republic of Uzbekistan "On protection of private property and guarantees of property rights", "On licensing procedures in the field of entrepreneurial activity", “On family business", "On guarantees of freedom of entrepreneurial activity" (in the new edition). ), "On measures to further strengthen the guarantees of women's labor rights and support entrepreneurship" [2] and the adoption of more than fifteen other normative acts on the employment of the working population, including women in entrepreneurship, business - creates favorable conditions for doing business and strengthens their position in the economy.

\section{RESULTS AND DISCUSSIONS}

Nowadays, about $50 \%$ of the population of Uzbekistan are women, their share is more than $82 \%$ in health and social services, $72 \%$ in science, education, culture and arts, $45 \%$ in agriculture and $38 \%$ in industry. [3]. It should be noted that women are not only the main source of the nation's gene pool, but also a major source of labor in the country's economy. Our country has created a unique model of state financial support for the involvement and support of women in entrepreneurship. The volume of loans provided by commercial banks for the comprehensive development of women's entrepreneurship is growing from year to year. Over the past two years, the People's Bank has allocated loans worth 32.2 billion soums for the implementation of 1,451 projects, and 4.5 billion soums for another 89 projects [4]. It should be noted that the tasks of the fourth direction of the Action Strategy for the five priority areas of development of the Republic of Uzbekistan for 2017-2021 - increasing the socio-economic activity of women, their involvement and development in entrepreneurship, expanding their rights and opportunities. Entrepreneurial Woman Association of Business Women of Uzbekistan has a special place. The activities of the Association of Women Entrepreneurs are aimed at creating favorable conditions for the active participation of women in market relations, supporting their entrepreneurial initiatives, protecting their rights and interests in business. The Association of Women Entrepreneurs has branches in 14 regions of the country. Today, the association has more than 14,000 women entrepreneurs. Over the past years, more than 200,000 new jobs have been created on the basis of projects implemented by members of the Association of Women Entrepreneurs. According to the social order of the Public Fund under the Oliy Majlis, "Wide involvement of graduates of secondary special and higher educational institutions, women and the disabled living in 10 districts of economic and social development below the national level in family business and various spheres of private entrepreneurship, providing them with modern The project "Supporting the mastery of information technology" was implemented, retraining 128 unemployed women in each district and training in the basics of business. A total of 1,024 unemployed women were involved in the process, and about 1,000 were employed.

The association is implementing a number of projects internationally. In particular, a special training program on the basics of business for young women entrepreneurs was held in cooperation with the Organization for Security and Cooperation in Europe under the project “Improving Women's Business Education and Development of Young Women's Entrepreneurship in Uzbekistan." Based on the program, participants visited the Netherlands and shared their experiences with their colleagues. In cooperation with the Islamic Development Bank, 15 women received small 
grants from the Islamic Development Bank under the "Employment of Women, Support for Socially Oriented Innovative Business Projects" project. With the support of the World Bank, the project "Development of the fruit and vegetable sector in Uzbekistan" provides close assistance to women working in farms, dehkan farms and horticulture [6]. The annual holding of the traditional ANOR contest by the Association of Business Women of Uzbekistan "Tadbirkor Ayol" in cooperation with the Association of Banks of Uzbekistan also serves to ensure the implementation of the above priorities. This year, the Association of Women Entrepreneurs of Uzbekistan with the support of the Ministry of Innovative Development of the Republic of Uzbekistan will implement the innovative project "Creation of a system of women's entrepreneurship in Uzbekistan in accordance with the International Global Index" to promote the business ecosystem and the potential of women entrepreneurs allows you to determine the rating. The Shark Ayoli International Women's Community Foundation is also implementing a number of projects to support women's entrepreneurship. In particular, the Public Fund funded a grant project "Development of ecommerce for women entrepreneurs in Tashkent region, improving the legislation of Uzbekistan and current areas of international regional cooperation in the field of ICT" with the participation of USAID experts under the USAID project "Development of Entrepreneurship and Business Environment". Within the framework of the Fund's state program "Year of Science, Education and Digital Economy", the project "Women and the Digital Economy" will be implemented in 7 cities and 15 districts of Tashkent region, according to which it is planned to cover 880 women and youth entrepreneurs [7]. Territorial subdivisions of the Association of Women Entrepreneurs in Khorezm, Kashkadarya, Namangan and Fergana regions, Mehr Bulogi NGO (Khorezm), Women and Joy in the competitions announced by the Public
Fund for Support of Non-Governmental Organizations and Other Civil Society Institutions under the Oliy Majlis in 2020 Grant funding of projects of the Center for Social Protection of Women and Youth (Surkhandarya) to support and develop women's entrepreneurship [8] Action Strategy, "Five Initiatives" and "Science, Education and Digital" proposed by the President of the Republic of Uzbekistan The Year of Economic Development shows that non-governmental non-profit organizations are actively involved in ensuring women's employment as an important social partner of the state. It should be noted that along with the achievements in this area, there are also shortcomings. Including, - NGO projects are not comprehensive from a regional point of view; Women's private entrepreneurship is more developed in cities. In rural areas, women are more involved in farming and sewing; - The seasonal nature of women's employment in rural areas remains more; - Although new jobs are important in the employment of women, their salaries are low.

\section{CONCLUSION}

In conclusion, the reforms will be effective in remote villages if NGOs, which have become important social partners of the state, expand their practical assistance in attracting rural women to their projects to support women's entrepreneurship, provide economic education, and obtain soft loans from banks.

\section{REFERENCES}

1. Journal of International Relations, 2001. № $2-p .4$

2. https // www.lex.uz.

3. Khalk suzi. Speech by President of the Republic of Uzbekistan Sh. Mirziyoyev at the solemn ceremony dedicated to the International Women's Day.08.03.2019.

4. https /www.xabar.uz. Khalk Bank provides soft loans to women.10.07.2019. 
The American Journal of Social Science and Education Innovations (ISSN - 2689-100x)

Published: November 30, 2020 | Pages: 463-466

5. O'zbekistonda tadbirkor ayollar soni // www.standart.uz.

6. https // O'z.A. Women entrepreneurs contribute to the development of the country.20.11.2019.

7. National database of NGOs of Uzbekistan // Materials of the International Women's Public Foundation "Shark Ayoli".

8. https //fundngo.uz. List of projects won by the Parliamentary Commission on the results of the 2nd competition of the Parliamentary Commission's Action Strategy for April 15-18, 2020 and the state grant on the implementation of the state program "Year of Science, Education and Digital Economy". 